\title{
18. ORGANIC PROPERTIES OF SEDIMENTS AND AMINO ACIDS IN INTERSTITIAL WATERS FROM THE FLANK OF THE COSTA RICA RIFT, GALAPAGOS SPREADING CENTER (ODP SITES 677 AND 678) ${ }^{1}$
}

\author{
Hodaka Kawahata $^{2}$ and Toshio Ishizuka ${ }^{3}$
}

\section{INTRODUCTION}

The basement at Ocean Drilling Program (ODP) Sites 677 and 678 originated from the Galapagos spreading center of the Costa Rica Rift and has moved about $200 \mathrm{~km}$ over the last 6 m.y. (Fig. 1) (Shipboard Scientific Party, 1987, 1988; Scientific Drilling Party, 1987). Sediments about $300 \mathrm{~m}$ thick cover basement so young that basal sediments at Sites 677 and 678 have been reheated up to $60^{\circ}-70^{\circ} \mathrm{C}$ at Site 677 and altered to limestone and/or chert (Shipboard Scientific Party, 1988). Sediments from both sites indicate (1) a high sedimentation rate (about $48 \mathrm{~m} / \mathrm{m} . \mathrm{y}$.) and (2) biogenic silica and carbonate as the main constituents of sediments (Table 1) (Shipboard Scientific Party, 1988). Heatflow observations and measurements of interstitialwater chemistry around the sites show that Site 677 is in a lower heatflow zone $\left(166 \mathrm{~mW} / \mathrm{m}^{2} ; 1^{\circ} 12.14^{\prime} \mathrm{N}, 83^{\circ} 44.22^{\prime} \mathrm{W}\right)$ whereas Site 678 is located in a zone of higher heat flow $\left(250 \mathrm{~mW} / \mathrm{m}^{2}\right.$; $1^{\circ} 13.01^{\prime} \mathrm{N}, 83^{\circ} 43.39^{\prime} \mathrm{W}$ ) (Langseth et al., 1988; Shipboard Scientific Party, 1988). In the flank hydrothermal systems, circulating solution is moving upward through the sedimentary column in zones of higher heat flow while it is moving downward in zones of lower heat flow (Anderson and Skilbeck, 1981).

The chemistry of the interstitial waters is modified by several processes such as (1) diagenetic reactions and (2) advective and (3) diffusive transports of dissolved constituents. Analyses of $\mathrm{Ca}^{2+}$ and $\mathrm{Mg}^{2+}$ in interstitial waters from Sites 677 and 678 show that their profiles are mainly controlled by advective transport (Shipboard Scientific Party, 1988). In contrast, the interstitial-water profiles for $\mathrm{NH}^{4+}, \mathrm{Si}$, and $\mathrm{PO}_{4}^{-3}$ are highly affected by reactions in the sediments. Site 677 offers a good opportunity to investigate amino acids in the interstitial waters because sediments of similar compositions have been deposited at constant rates of sedimentation. There are few previous works on amino acid distributions in interstitial waters (Henrichs and Farrington, 1979; Michaelis et al., 1982; Henrichs et al., 1984; Henrichs and Farrington, 1987; Ishizuka et al., 1988).

In this chapter, we report (1) Rock-Eval analysis and (2) the composition of total hydrolyzable and dissolved free amino acids (THAA and DFAA, respectively) in the interstitial waters. Our objectives are to discuss (1) the possible origin of organic materials, (2) the characteristics of THAA and DFAA, and (3) their relationships in interstitial waters.

\section{METHODS}

\section{Sampling and Storage}

Interstitial-water samples from Sites 677 and 678 were collected aboard JOIDES Resolution by hydraulic squeezing at the same tempera-

\footnotetext{
${ }^{1}$ Becker, K., Sakai, H., et al., 1989. Proc. ODP, Sci. Results, 111: College Station, TX (Ocean Drilling Program).

2 Geological Survey of Japan, Higashi, Tsukuba, Ibaraki, 305, Japan.

3 Ocean Research Institute, University of Tokyo, Minamidai, Nakano, Tokyo,
}

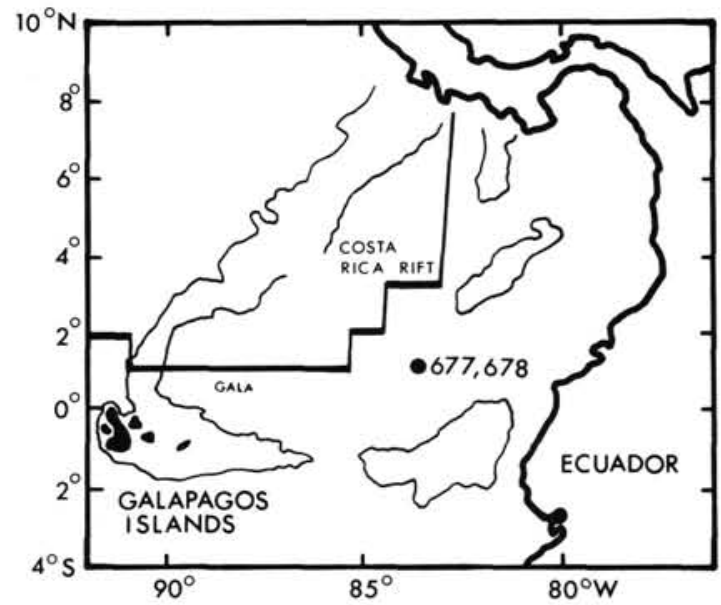

Figure 1. Location of ODP Sites 677 and 678 in the Panama Basin of the Costa Rica Rift. Water depths at Sites 677 and 678 are 3461 and $3435 \mathrm{~m}$, respectively.

ture at which the sediment was recovered. All interstitial-water samples were filtered through $0.22-\mu \mathrm{m}$ Millipore cellulose acetate filters in the shipboard laboratory. For amino acid analysis of interstitial water, a $5-\mathrm{mL}$ aliquot of the water sample was placed into a precombusted glass ampule. The ampule was sealed after flushing with helium, stored in a refrigerator aboard ship, and returned to the shorebased laboratory for analysis.

\section{Analytical Procedures}

\section{Amino Acids}

Interstitial-water DFAA was analyzed after the addition of $7 \mu \mathrm{L}$ of ultrapure (amino acid-free) $17 \% \mathrm{HCl}$ to $0.7 \mathrm{~mL}$ of an interstitial-water sample. Each amino acid concentration was determined by direct injection into an automated liquid chromatograph (Hitachi Model 835). The reagent blank was suitably corrected.

For THAA, a 1-mL interstitial-water sample, together with $1 \mathrm{~mL}$ of ultrapure $17 \% \mathrm{HCl}$, was placed in a precombusted glass ampule, and hydrolysis was conducted at $110^{\circ} \mathrm{C}$ for $22 \mathrm{hr}$ under an argon atmosphere. Then, the solution was gently evaporated using a rotary evaporator at a temperature lower than $42^{\circ} \mathrm{C}$, and the residue was redissolved in $1 \mathrm{~mL}$ of $0.01 \mathrm{M} \mathrm{HCl}$. The resulting aliquot was injected into the amino acid analyzer. The standard deviation for amino acid analysis based on replicated measurements of a standard solution (about $\mu \mathrm{mol} / \mathrm{L}$ for amino acids) was less than $10 \%$, and the detection limit of our method was about $0.05 \mu \mathrm{mol} / \mathrm{L}$. Low values in free and hydrolyzable amino acids near the detection limit may not be dependable. Nevertheless, we retain these values because they confirm that the amino acid concentration is low (Ishizuka et al., 1988).

\section{Rock-Eval Analysis}

After squeezing, remnants of the interstitial-water sediment samples were oven-dried at $60^{\circ} \mathrm{C}$ and ground into powder. These samples were analyzed by pyrolysis in the shipboard Rock-Eval unit. 
Table 1. Characteristics of lithologic units, Holes 677A and 678B.

\begin{tabular}{|c|c|c|c|c|c|c|}
\hline Unit & $\begin{array}{l}\text { Depth } \\
\text { (mbsf) }\end{array}$ & Lithology & Age & $\begin{array}{l}\text { Porosity } \\
(\%)\end{array}$ & $\begin{array}{l}\text { Density }{ }^{\mathrm{a}} \\
\left(\mathrm{g} / \mathrm{cm}^{3}\right)\end{array}$ & $\begin{array}{l}\text { Sedimentation } \\
\text { rate } \\
(\mathrm{m} / \mathrm{m} . \mathrm{y} .)\end{array}$ \\
\hline \multicolumn{7}{|c|}{ Hole 677A } \\
\hline I & $0-153.8$ & $\begin{array}{l}\text { Alternating clayey biogenic } \\
\text { calcareous siliceous } \\
\text { oozes and clayey } \\
\text { biogenic siliceous } \\
\text { calcareous oozes }\end{array}$ & $\begin{array}{l}\text { early Pliocene-late } \\
\text { Pleistocene }\end{array}$ & 90 & 1.2 & 48 \\
\hline II & $153.8-308.5$ & $\begin{array}{l}\text { Siliceous nannofossil and } \\
\text { nannofossil chalk }\end{array}$ & late Miocene & 70 & 1.8 & 48 \\
\hline III & $303.3-308.5$ & $\begin{array}{l}\text { Cherty limestone and } \\
\text { nannofossil chalk }\end{array}$ & late Miocene & 50 & 1.8 & 48 \\
\hline IV & $308.5-309.5$ & $\begin{array}{l}\text { Iron oxide- and smectite- } \\
\text { rich sediments inter- } \\
\text { mixed with glassy } \\
\text { basement basalts }\end{array}$ & late Miocene & & & \\
\hline \multicolumn{7}{|c|}{ Hole 678B } \\
\hline I & $0-27.7$ & $\begin{array}{l}\text { Clayey calcareous siliceous } \\
\text { ooze }\end{array}$ & $\begin{array}{l}\text { late Pliocene-late } \\
\text { Pleistocene }\end{array}$ & 83 & 1.3 & \\
\hline II & $95.5-111.8$ & $\begin{array}{l}\text { Clayey diatom nannofossil } \\
\text { chalk }\end{array}$ & late Miocene & 77 & 1.4 & \\
\hline III & $111.8-169.8$ & Limestone & late Miocene & 75 & 1.5 & \\
\hline IV & $169.8-170.1$ & $\begin{array}{l}\text { Basalt fragments and } \\
\text { conglomerates }\end{array}$ & late Miocene & & & \\
\hline
\end{tabular}

${ }^{\text {a }}$ Mean values.

\section{RESULTS}

\section{Pyrolysis Assay (Rock-Eval)}

The total organic carbon (TOC) content of the sediment residues from the interstitial-water squeezing process is highly variable, but appears to have a generally decreasing trend with depth. TOC values range from 0.10 to $0.81 \mathrm{wt} \%$, except for a single sample with $2.92 \mathrm{wt} \%$ (Table 2 and Fig. 2). The maximum TOC value occurs at about $80 \mathrm{~m}$ below seafloor (mbsf). The values are similar to those from Hole 678B.

The total hydrocarbon yields, S1 (free, distillable hydrocarbons) + S2 (generatable hydrocarbons), from Holes 677A and 678B are low (0-9 mg hydrocarbons/g rock) and show the same profile as the TOC. The oxygen index $(\mathrm{OI}=\mathrm{S} 3 / \mathrm{TOC})$ is highly scattered, with a mean value of 644 . Most of the organic matter is highly oxidized, as indicated by the high $\mathrm{OI}$ values. The hydrogen index $(\mathrm{HI}=\mathrm{S} 2 / \mathrm{TOC})$ ranges from 0 to 292 , and its mean value is 126 (Table 2 and Fig. 2).

Pyrolysis offers an indication of organic maturity through $\mathrm{T}_{\max }$, the temperature at which there is maximum hydrocarbon generation. $T_{\max }$ values from Sites 677 and 678 are up to $419^{\circ} \mathrm{C}$ (Table 2 and Fig. 2), indicating that the organic matter is thermally immature and has not entered into the stage of peak hydrocarbon generation.

\section{THAA in Interstitial Waters}

The concentrations of individual THAA are given in Table 3 . The total concentration of THAA ranges from 1.80 to 31.50 $\mu \mathrm{mol} / \mathrm{L}$, averaging $8.34 \mu \mathrm{mol} / \mathrm{L}$. Relatively high values are found at near the surface and at depths of $25.8,196.6$, and $274.2 \mathrm{mbsf}$ (Fig. 3). The THAA profile is different from those of dissolved $\mathrm{Ca}^{2+}$ and $\mathrm{Mg}^{2+}$ measured in interstitial waters, which are mainly controlled by downward advective flow (Shipboard Scientific Party, 1987).

In spite of high fluctuations of THAA, the relative abundance of individual amino acids is similar throughout the hole. The mean values of acidic, basic, neutral, aromatic, and sulfurcontaining amino acids are $2.28,1.25,4.62,0.24$, and 0.01 $\mu \mathrm{mol} / \mathrm{L}$, respectively.

\section{DFAA in Interstitial Waters}

The concentrations of individual DFAA are given in Table 4. The total concentration of amino acids ranges from 0.20 to 11.8 $\mu \mathrm{mol} / \mathrm{L}$, averaging $3.19 \mu \mathrm{mol} / \mathrm{L}$. Relatively high values are found near the surface and at depths of $25.8,179.2$, and $285.0 \mathrm{mbsf}$ (Fig. 3). The total DFAA profile vs. sub-bottom depth correlates with that of total THAA.

The data in Table 4 reveal the following general order of amino acid abundance: neutrals $>$ basics $>$ acids $>$ aromatics $>$ sulfur-containing. The mean values of acidic, basic, neutral, aromatic, and sulfur-containing amino acids are $0.18,0.67,2.24$, 0.08 , and $0.00 \mu \mathrm{mol} / \mathrm{L}$, respectively.

\section{DISCUSSION}

\section{Organic Material from Sites 677 and 678}

The TOC values from Holes 677A and 678B are, in general, high compared with those recorded in open-marine deep-sea sediments, which are usually less than $0.3 \mathrm{wt} \%$ (McIver, 1975). The high values are probably caused (1) by high oceanic productivity, such as in equatorial upwelling areas, and (2) by rapid burial of organic carbon $\left(\mathrm{C}_{\text {org }}\right)$ as a result of high sedimentation rates. These reasons are supported by two observations: (1) that biogenic siliceous and calcareous fragments, which have supplied much of the organic carbon, constitute the sediments at Sites 677 and 678 and (2) that much framboidal pyrite formed as a result of the reduction of sulfate ions in the interstitial water by organic materials occurring throughout the hole.

The HI and OI values determined by Rock-Eval analyses are plotted in Figure 4 on a van Krevelen diagram (Tissot and Welte, 1984). This diagram implies that most of the organic matter in the sediments at Sites 677 and 678 is of a type II/III mixture, that is, a mixture of marine and terrigenous organic matter. A large contribution of terrestrial organic matter seems unlikely, however, because the terrigenous inorganic constituents (e.g., feldspar and quartz) make up only about $1 \%-4 \%$ of the total sediments, whereas marine biogenic fragments comprise about $70 \%-90 \%$, based upon our microscopic examination. In addi- 
Table 2. Rock-Eval analysis.

\begin{tabular}{|c|c|c|c|c|c|c|c|c|c|}
\hline $\begin{array}{l}\text { Core, section, } \\
\text { interval }(\mathrm{cm})\end{array}$ & $\begin{array}{l}\text { Depth } \\
\text { (mbsf) }\end{array}$ & $\begin{array}{c}\text { TOC } \\
\text { (wt \%) }\end{array}$ & $\begin{array}{l}\mathrm{S} 1 \\
\text { (mg } \\
\text { carb } \\
\mathrm{g} \mathrm{r}\end{array}$ & $\begin{array}{l}\text { S2 } \\
\text { ydro- } \\
\text { ons/ } \\
\text { ck) }\end{array}$ & $\begin{array}{c}\mathrm{S}^{3} \\
\text { (mg rock) }\end{array}$ & $\mathrm{S} 1+\mathrm{S} 2$ & $\begin{array}{c}\text { HI } \\
\text { (mg S2 } \\
\text { hydrocarbons/g } \\
\text { organic } \\
\text { carbon) }\end{array}$ & $\begin{array}{c}\mathrm{OI} \\
(\mathrm{mg} \mathrm{S} 3 \\
\mathrm{CO}_{2} / \mathrm{g} \\
\text { organic } \\
\text { carbon) }\end{array}$ & $\begin{array}{l}\mathrm{T}_{\max } \\
\left({ }^{\circ} \mathrm{C}\right)\end{array}$ \\
\hline \multicolumn{10}{|l|}{$111-677 \mathrm{~A}$ - } \\
\hline $1 \mathrm{H}-3,145-150$ & 4.5 & 0.41 & 0.18 & 0.85 & 2.93 & 1.03 & 207 & 714 & 389 \\
\hline $2 \mathrm{H}-1,80-89$ & 7.0 & 0.70 & 0.21 & 1.23 & 4.13 & 1.44 & 175 & 590 & 396 \\
\hline $3 \mathrm{H}-4,120-125$ & 21.4 & 0.90 & 0.28 & 2.00 & 4.04 & 2.28 & 222 & 448 & 413 \\
\hline $4 \mathrm{H}-1,55-74$ & 25.8 & 0.58 & 0.19 & 0.94 & 3.72 & 1.13 & 162 & 641 & 411 \\
\hline $5 \mathrm{H}-1,51-69$ & 35.3 & 0.49 & 0.24 & 0.75 & 4.45 & 0.99 & 153 & 908 & 385 \\
\hline $6 \mathrm{H}-3,120-125$ & 48.4 & 0.74 & 0.19 & 0.93 & 3.81 & 1.12 & 125 & 514 & 406 \\
\hline $9 \mathrm{H}-3,120-125$ & 76.9 & 2.91 & 0.55 & 8.51 & 4.80 & 9.06 & 292 & 164 & 419 \\
\hline $12 \mathrm{H}-4,120-125$ & 106.9 & 0.32 & 0.13 & 0.44 & 3.46 & 0.57 & 137 & 1081 & 391 \\
\hline $13 \mathrm{H}-4,145-150$ & 116.7 & 0.27 & 0.09 & 0.38 & 2.20 & 0.47 & 140 & 814 & 393 \\
\hline $14 \mathrm{H}-4,145-150$ & 126.2 & 0.70 & 0.16 & 1.20 & 3.11 & 1.36 & 171 & 444 & 413 \\
\hline $15 \mathrm{H}-4,120-125$ & 135.4 & 0.28 & 0.09 & 0.31 & 2.82 & 0.40 & 110 & 1007 & 389 \\
\hline $16 X-4,145-150$ & 145.2 & 0.38 & 0.11 & 0.33 & 2.27 & 0.44 & 86 & 597 & 392 \\
\hline $17 X-3,145-150$ & 148.7 & 0.30 & 0.45 & 0.27 & 2.01 & 0.72 & 90 & 670 & 392 \\
\hline $18 X-3,120-125$ & 158.0 & 0.39 & 0.08 & 0.35 & 2.36 & 0.43 & 89 & 605 & 393 \\
\hline $19 X-4,145-150$ & 169.5 & 0.17 & 0.08 & 0.17 & 2.06 & 0.25 & 100 & 1211 & 384 \\
\hline $20 X-4,145-150$ & 179.2 & 0.32 & 0.09 & 0.43 & 1.32 & 0.52 & 134 & 412 & 406 \\
\hline $22 \mathrm{X}-3,120-125$ & 196.6 & 0.41 & 0.10 & 0.21 & 1.33 & 0.31 & 51 & 324 & 395 \\
\hline $23 \mathrm{X}-4,145-150$ & 208.1 & 0.13 & 0.10 & 0.11 & 1.08 & 0.21 & 84 & 830 & 388 \\
\hline $25 \times-4,120-125$ & 227.1 & 0.12 & 0.03 & 0.16 & 1.14 & 0.19 & 133 & 950 & 400 \\
\hline $27 \times-4,145-150$ & 246.8 & 0.29 & 0.04 & 0.40 & 1.10 & 0.44 & 137 & 379 & 406 \\
\hline $29 \mathrm{X}-3,145-150$ & 264.5 & 0.14 & 0.03 & 0.16 & 1.10 & 0.19 & 114 & 785 & 396 \\
\hline $31 \times-4,120-125$ & 285.0 & 0.10 & 0.04 & 0.17 & 1.08 & 0.21 & 170 & 1080 & 400 \\
\hline $33 \mathrm{X}-2,145-150$ & 301.6 & 0.11 & 0.02 & 0.08 & 0.89 & 0.10 & 72 & 809 & 392 \\
\hline $33 \mathrm{X}-3,133-150$ & 303.0 & 0.18 & 0.02 & 0.14 & 0.92 & 0.16 & 77 & 511 & 416 \\
\hline \multicolumn{10}{|l|}{ 111-678B- } \\
\hline $1 \mathrm{H}-1,45-50$ & 0.5 & 0.86 & 0.29 & 1.61 & 4.70 & 1.90 & 187 & 546 & 417 \\
\hline $1 \mathrm{H}-2,145-150$ & 3.0 & 0.67 & 0.37 & 1.19 & 4.57 & 1.56 & 177 & 682 & 398 \\
\hline $2 \mathrm{H}-1,145-150$ & 19.7 & 0.61 & 0.14 & 0.62 & 3.41 & 0.76 & 101 & 559 & 397 \\
\hline $2 \mathrm{H}-4,145-150$ & 24.2 & 0.51 & 0.14 & 0.58 & 3.62 & 0.72 & 113 & 709 & 388 \\
\hline $3 \mathrm{H}-1,145-150$ & 97.0 & 0.45 & 0.04 & 0.30 & 1.80 & 0.34 & 66 & 400 & 399 \\
\hline $3 \mathrm{H}-6,145-150$ & 104.5 & 0.51 & 0.07 & 0.53 & 1.85 & 0.60 & 103 & 362 & 402 \\
\hline $4 \mathrm{~W}-3,95-107$ & 138.9 & 0.33 & 0.03 & 0.13 & 1.82 & 0.16 & 39 & 551 & 391 \\
\hline 4W-CC, $3-15$ & 168.9 & 0.26 & 0.00 & 0.00 & 0.77 & 0.00 & 0 & 296 & 337 \\
\hline
\end{tabular}

tion, marine sediments off coasts generally have a predominance of marine organic matter. The characteristics of OI and $\mathrm{HI}$ of original organic material may be overprinted by the mechanisms of (1) the effect by microbiological degradation (Whelan and Tarafa, 1986) and (2) degradation by montmorillonite catalysis (Whelan and Hunt, 1983).

\section{Amino Acids in Interstitial Waters}

\section{Characteristics of THAA}

The characteristics of THAA from Hole 677A are as follows:

1. THAA concentrations are similar to the values found for biogenic carbonate-rich sediments from the Atlantic Ocean (Ishizuka et al., 1988).

2. Glutamic and aspartic acids, glycine, and serine are the major constituents.

3. THAA composition of interstitial waters is fairly uniform throughout the hole (Table 3 ).

These characteristics are explained by (1) the THAA compositions and concentrations of the original seawater trapped with the sediment particles when they were deposited, (2) the THAA compositions and concentrations of proteinaceous materials in sediment particles, (3) the production rate of THAA from sediment by chemical and biological processes, (4) the decomposition rate of THAA in interstitial waters, and (5) the water content or porosity.
The porosity of the sediments from Hole $677 \mathrm{~A}$ averages about $90 \%$ in lithologic Unit I and decreases to $50 \%$ in Unit III (Table 1). There is no correlation between porosity and composition of THAA in the interstitial waters of Hole 677A.

THAA of deep-sea water from the Pacific Ocean shows (1) that alanine accounts for up to $60 \%-70 \%$ of the total amino acids in seawater and (2) that the total concentration of THAA is less than $100 \mathrm{nmol} / \mathrm{kg}$ (Bada et al., 1982). Because the concentrations of total THAA and DFAA of interstitial water from Hole $677 \mathrm{~A}$ are about 8.34 and $3.19 \mu \mathrm{mol} / \mathrm{L}$, respectively, the concentration of THAA in the original seawater must have been one or two orders lower in magnitude. Reaction between interstitial water and sediments during early diagenesis plays an important role in the large discrepancy between the amino acid composition of THAA of seawater and interstitial waters.

\section{Sources of THAA}

Planktonic and terrestrial organic matters are considered to be the most important amino acid contributors in view of the Rock-Eval analyses, smear slide observations, and the inorganic chemistry of sediments from Sites 677 and 678. Fragments of the calcareous and siliceous microfossils make up about $70 \%$ $90 \%$ of the total sediments. Aluminous smectites, quartz, feldspars, and rutile were transported from land and deposited at Sites 677 and 678 (Beiersdorf and Rosch, 1983; Beiersdorf and Natland, 1983). Relative abundances of acidic, basic, and neutral amino acids of DFAA and THAA in the interstitial waters are plotted as a function of sub-bottom depth in Figure 5. The relative abundances are uniform, especially in the upper $220 \mathrm{~m}$ 

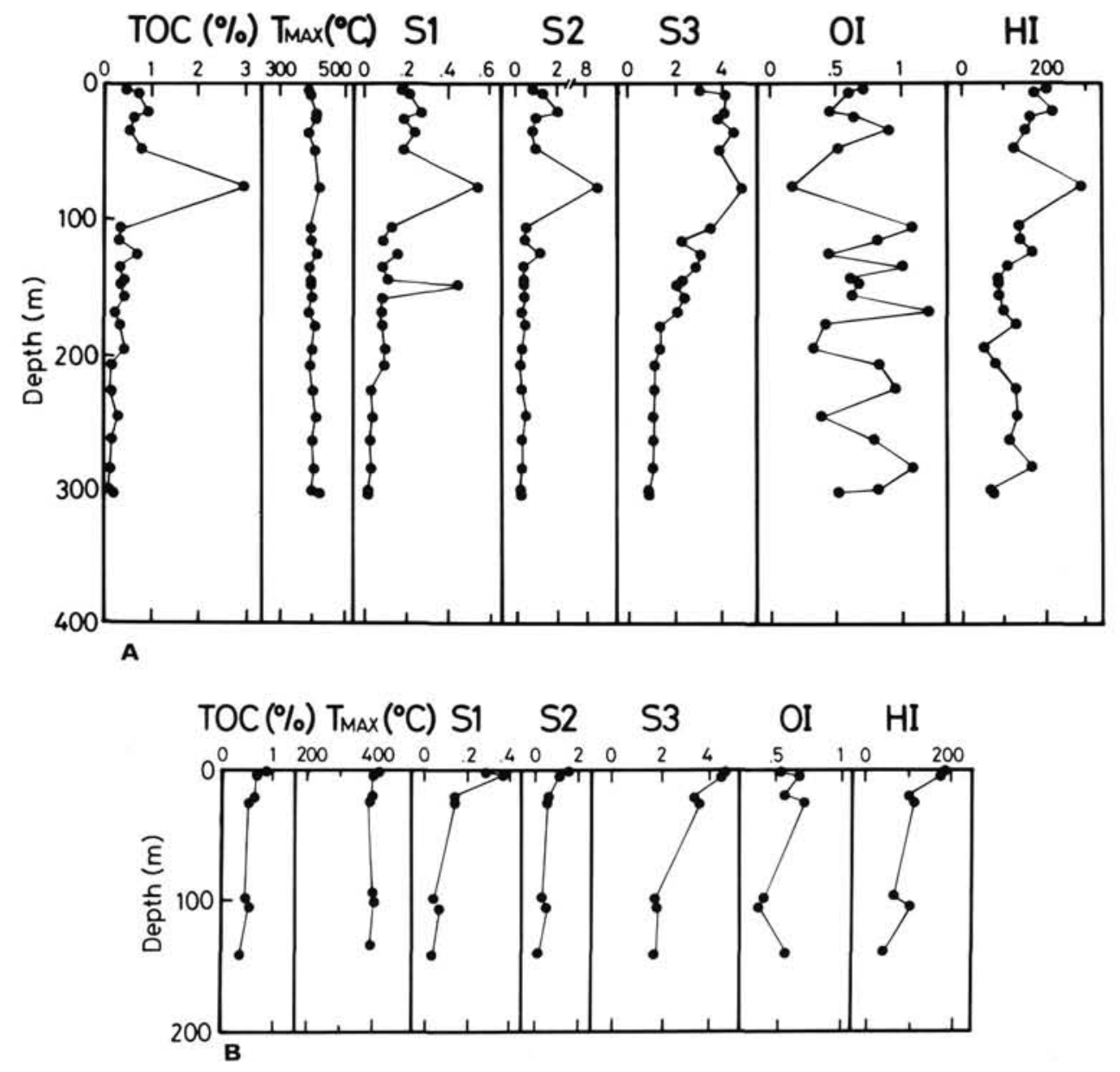

Figure 2. TOC, HI, OI, S1, S2, and S3 vs. sub-bottom depth. A. Hole 677A. B. Hole 678B.

of sediments, in spite of large fluctuations in the concentrations. The relation between neutral, acidic, and basic amino acids is shown in Figure 6. The correlation factors of neutral to acidic and basic of THAA are 0.90 and 0.72 , respectively. These results indicate that simple decomposition of proteinaceous materials in the sediments plays a more important role than discrimination by bacteria in determining the compositions of THAA.

Examination of the qualitative data in Table 3 reveals the order of abundance as neutral $>$ acidic $>$ basic $>$ aromatics $>$ sulfur-containing. In comparison, examination of planktonic amino acid composition in Table 5 (Morris, 1975; Raymont et al., 1975) gives a predominance of neutral over acidic and acidic over basic.

As far as the neutral fraction is concerned, the relative abundance of straight-branch fractions dominates. The ratio between glycine and alanine in Hole 677A is similar to that found in plankton and marine suspensions (Raymont et al., 1975; Ittekkot et al., 1984). The second dominant fraction is the hydroxy amino acids. Within the hydroxy fraction there is a general predominance of serine, as is seen in the plankton, in contrast to the predominance of threonine over serine in sediments enriched in algal cellular debris (Gonzalez et al., 1983). Threonine, serine, and glycine are the main components of a proteinsilica complex in diatom cell walls that should be particularly resistant to environmental degradation (Siezen and Magne, 1978). The diatomaceous silica fragments account for $19 \%$ of the total sediments in lithologic Unit I and $14 \%$ in Unit II. These lines of evidence suggest that proteins from diatoms contribute as one of the important sources of THAA of interstitial waters. Branched-chain amino acids, including valine, leucine, and isoleucine, in Hole $677 \mathrm{~A}$ interstitial-water THAA are as abundant as those in plankton.

Within the acidic fraction the relative abundance of glutamic acid is twice that of aspartic acid in plankton. In addition, significant amounts of glutamic acid are contained by marine bacteria (Henrichs and Farrington, 1979) and by oceanic suspended particulate matter (Siezen and Magne, 1978). This contrasts with the predominance of aspartic acids over glutamic acid found in terrestrial humic hydrolates, river suspensions, and sediments rich in terrestrial organic material (Peake et al., 1972; Khan and Sowden, 1972; Pelet and Debyser, 1977). Glutamic acid has three times the concentration of aspartic acid, accounting for $18 \%$ of the total THAA, which is consistent with the composition of plankton.

Within the basic fraction of Hole 677A ornithine is the major amino acid and arginine is the minor one in spite of the predominance of arginine over ornithine in marine plankton. The ratio from Hole 677A probably resulted from the decomposition from arginine and transformation to ornithine during early diagenesis.

Aromatic and sulfur-containing amino acids are depleted in THAA in the interstitial waters from Hole 677A. Nissenbaum et al. (1972) reported the predominance of phenylalanine with the oxidizing conditions of deposition. The low content of phenylalanine of THAA in Hole 677A is probably due to reducing conditions resulting from the large supply of organic carbon, in 


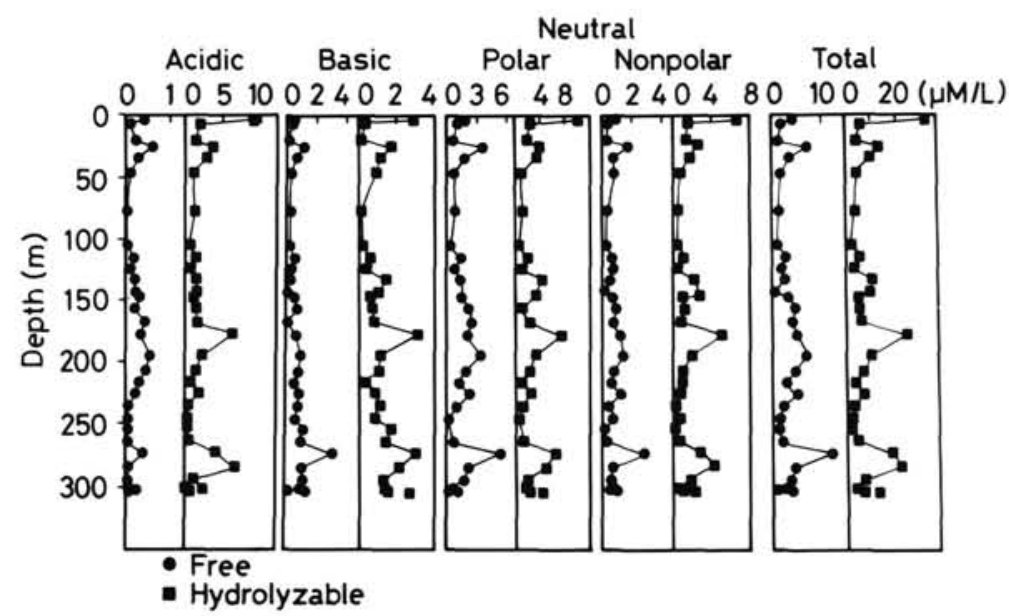

Figure 3. Concentrations of acidic, basic, neutral, and total amino acids of THAA and DFAA in interstitial waters vs. sub-bottom depth in Hole 677A.

consideration of the abundance of framboidal sulfides (about 1 wt $\%$ ) occurring throughout the hole.

\section{Comparison of DFAA to Other Fields}

The DFAA concentrations are of the same order of magnitude as those from the coastal region of Buzzards Bay (Massachusetts) and the upwelling regions off Peru, although the values from the surface to $20 \mathrm{~cm}$ in the sediment of coastal and upwelling regions are one or two orders higher (Henrichs et al., 1984; Henrichs and Farrington, 1987). The DFAA of the North Atlantic Ocean abyssal plain is one order of magnitude lower (Ishizuka et al., 1988). These concentrations are probably highly affected by TOC. Relatively organic-rich sediments (TOC $>0.5$ wt $\%$ ) show DFAA values on the order of $10 \mu \mathrm{mol} / \mathrm{L}$ whereas the DFAA concentrations are very low $(<1 \mu \mathrm{mol} / \mathrm{L})$ in organicpoor sediments (TOC $<0.2 \mathrm{wt} \%)$.

Relative abundances of acidic, basic, and neutral amino acids in the interstitial waters are uniform, especially in the upper $220 \mathrm{~m}$ of sediments, as evidenced by THAA (Fig. 5). The correlation factors of neutral to acidic and neutral to basic are 0.67 and 0.74 , respectively (Fig. 6). The DFAA compositions of Hole $677 \mathrm{~A}$ are different than those from estuary and hemipelagic sediments. Glycine, alanine series, and orthine are the major constituents of the DFAA in Hole 677A. Acidic amino acids-including aspartic $(3 \mathrm{~mol} \%)$ and glutamic $(5 \mathrm{~mol} \%)$ acids-are minor constituents. In hemipelagic and coastal sediments, glutamic acid is commonly the major constituent (Henrichs et al., 1984; Henrichs and Farrington, 1987).

\section{Relation between THAA and DFAA}

Interesting characteristics of the relation between THAA and DFAA in Hole 677A are (1) the good correlation between total THAA and total DFAA, (2) a much lower concentration of acidic amino acid fractions in DFAA than in THAA, (3) higher concentrations of hydroxyl and straight-branched amino acid fractions in DFAA than in THAA, and (4) very low concentrations of aromatic and sulfur-containing fractions in DFAA and THAA.

The relative abundance of acidic amino acids in DFAA is only one-third that of THAA in Hole 677A (Fig. 5), although the acidic amino acids are more stable than the basic amino acids in the free state (Abelson, 1959). Based on the results of adsorption experiments of amino acids in distilled water, basic (positively charged) amino acids were strongly adsorbed $(40 \%$ $80 \%$ removal) and neutral (uncharged) amino acids were taken up appreciably $(10 \%-15 \%)$ by montmorillonite. Acidic (negatively charged) acids were adsorbed very little (Hedges and Hare, 1987). Stevenson and Cheng (1969) found that basic amino acids are more apt to be incorporated into the lattice of clay minerals than acidic amino acids are in the Argentine Basin sediments. Montmorillonites are the major clay minerals in Hole 677A, accounting for $2 \%-40 \%$ of the total sediment composition, but they are not capable of controlling the composition of amino acids by adsorption. Furthermore, quartz does not have the ability to selectively adsorb aspartic acid-rich organic matter (Carter, 1978).

Acidic amino acids inhibit the reaction with calcite, which can be best explained by a specific epitaxial effect in which aspartic or glutamic acid forms a protective overgrowth on the carbonate surface (Jackson and Bischoff, 1971). Carter (1978) and Carter and Mittere (1978) indicated that the carbonate surface appears to selectively adsorb aspartic acid-enriched organic matter whereas noncarbonates do not have this property. Biogenic carbonate fractions in the sediments from Hole 677A make up $40 \%$ of the total sediments, and the low concentration of acidic amino acids of DFAA is probably due to reaction or adsorption with carbonates.

\section{SUMMARY AND CONCLUSIONS}

Biogenic siliceous and calcareous sediments were drilled at Sites 677 and 678 on the flank of Costa Rica Rift during ODP Leg 111.

1. The TOC values of the sediments range from 0.10 to 2.91 wt $\%$. Mean values of $\mathrm{OI}$ and $\mathrm{HI}$ are 644 and 126 , respectively. $\mathrm{T}_{\max }$ values from Sites 677 and 678 are up to $419^{\circ} \mathrm{C}$, indicating that the organic matter is thermally immature.

2. The total concentration of THAA ranges from 1.80 to $31.50 \mu \mathrm{mol} / \mathrm{L}$, averaging $8.34 \mu \mathrm{mol} / \mathrm{L}$. The mean values $\mathrm{cf}$ acidic, basic, neutral, aromatic, and sulfur-containing amino acids are $2.28,1.25,4.62,0.24$, and $0.01 \mu \mathrm{mol} / \mathrm{L}$, respectively.

3. The total concentration of DFAA ranges from 0.20 to $11.80 \mu \mathrm{mol} / \mathrm{L}$, averaging $3.19 \mu \mathrm{mol} / \mathrm{L}$. The profile of total DFAA is relatively consistent with that of total THAA from Hole $677 \mathrm{~A}$. The mean values of acidic, basic, neutral, aromatic, and sulfur-containing amino acids are $0.18,0.67,2.24,0.08$, and $0.0 \mu \mathrm{mol} / \mathrm{L}$, respectively.

4. The most plausible source of THAA is marine plankton, based upon the comparison of amino acid compositions between THAA, plankton, and river suspensions. 
Table 3. Concentrations of THAA in interstitial-water samples from Hole 677A.

\begin{tabular}{|c|c|c|c|c|c|c|c|c|c|c|c|c|c|c|}
\hline Depth (mbsf) & $\begin{array}{c}1 \mathrm{H}-3, \\
145-150 \\
4.5\end{array}$ & $\begin{array}{c}2 \mathrm{H}-1, \\
80-89 \\
7.0\end{array}$ & $\begin{array}{c}3 \mathrm{H}-4, \\
120-125 \\
21.4\end{array}$ & $\begin{array}{c}4 \mathrm{H}-1, \\
55-74 \\
25.8\end{array}$ & $\begin{array}{c}5 H-1, \\
51-69 \\
35.3\end{array}$ & $\begin{array}{c}6 \mathrm{H}-3, \\
120-125 \\
48.4\end{array}$ & $\begin{array}{c}9 \mathrm{H}-3, \\
120-125 \\
76.9\end{array}$ & $\begin{array}{c}12 \mathrm{H}-4 \\
120-125 \\
106.9\end{array}$ & $\begin{array}{c}13 \mathrm{H}-4 \\
145-150 \\
116.7\end{array}$ & $\begin{array}{c}14 \mathrm{H}-4, \\
145-150 \\
126.2\end{array}$ & $\begin{array}{c}15 \mathrm{H}-4 \\
120-125 \\
135.4\end{array}$ & $\begin{array}{c}16 X-4 \\
145-150 \\
145.2\end{array}$ & $\begin{array}{c}17 X-3 \\
145-150 \\
148.7\end{array}$ & $\begin{array}{c}18 X-3 \\
120-125 \\
158.0\end{array}$ \\
\hline \multicolumn{15}{|l|}{ Acidic $(\mu \mathrm{mol} / \mathrm{L})$} \\
\hline Aspartic acid & 3.29 & 0.36 & 0.26 & 0.78 & 0.73 & 0.18 & 0.21 & 0.18 & 0.45 & 0.19 & 0.56 & 0.53 & 0.26 & 0.31 \\
\hline Glutamic acid & 5.86 & 1.48 & 1.03 & 2.75 & 2.04 & 0.85 & 0.85 & 0.34 & 0.91 & 0.52 & 0.84 & 0.78 & 0.74 & 1.09 \\
\hline \multicolumn{15}{|l|}{ Basic } \\
\hline Ornithine & 0.23 & 0.15 & 0.07 & 0.99 & 0.67 & 0.72 & 0.14 & 0.13 & 0.41 & 0.20 & 0.83 & 0.50 & 0.42 & 0.52 \\
\hline Lysine & 0.83 & 0.14 & 0.08 & 0.25 & 0.16 & 0.05 & 0.05 & 0.04 & 0.11 & 0.04 & 0.16 & 0.21 & 0.14 & 0.14 \\
\hline Histidine & 0.52 & 0.06 & - & 0.36 & 0.31 & 0.13 & 0.04 & 0.01 & 0.09 & 0.14 & 0.36 & 0.08 & 0.07 & 0.18 \\
\hline Arginine & 1.33 & 0.03 & - & 0.09 & - & - & 0.02 & - & 0.02 & - & 0.14 & 0.22 & 0.01 & 0.02 \\
\hline \multicolumn{15}{|l|}{ Neutral } \\
\hline \multicolumn{15}{|l|}{ Hydroxy } \\
\hline Threonine & 2.34 & 0.38 & 0.25 & 0.52 & 0.48 & 0.10 & 0.13 & 0.07 & 0.23 & 0.08 & 0.47 & 0.42 & 0.16 & 0.21 \\
\hline Serine & 2.75 & 0.34 & 0.13 & 1.45 & 1.21 & 0.19 & 0.28 & 0.19 & 0.78 & 0.33 & 1.74 & 1.14 & 0.59 & 0.88 \\
\hline \multicolumn{15}{|l|}{ Straight } \\
\hline Glycine & 4.87 & 1.09 & 0.71 & 2.19 & 1.58 & 0.56 & 0.55 & 0.40 & 0.82 & 0.52 & 2.09 & 1.60 & 0.89 & 1.25 \\
\hline Alanine & 2.69 & 0.83 & 0.46 & 1.12 & 0.77 & 0.34 & 0.33 & 0.22 & 0.48 & 0.36 & 1.01 & 1.15 & 0.46 & 0.69 \\
\hline \multicolumn{15}{|l|}{ Branch } \\
\hline Valine & 1.61 & 0.02 & 0.02 & 0.60 & 0.44 & 0.18 & 0.34 & 0.14 & 0.35 & 0.35 & 0.46 & 0.58 & 0.20 & 0.48 \\
\hline Iso-leucine & 1.29 & 0.12 & 0.10 & 0.75 & 0.16 & 0.08 & 0.10 & 0.09 & 0.13 & 0.10 & 0.65 & 0.76 & 0.13 & 0.07 \\
\hline Leucine & 2.27 & 0.55 & 0.56 & 0.66 & 0.50 & 0.39 & 0.09 & 0.05 & 0.51 & 0.31 & 0.46 & 0.68 & 0.43 & 0.55 \\
\hline \multicolumn{15}{|l|}{ Others } \\
\hline $\begin{array}{l}\text { Aspargine } \\
\text { Aromatic }\end{array}$ & - & - & - & - & - & - & - & - & 0.09 & - & - & - & - & - \\
\hline Tyrosine & 0.76 & - & - & 0.16 & 0.14 & - & - & - & - & - & - & 0.14 & 0.10 & - \\
\hline $\begin{array}{l}\text { Phenylalanine } \\
\text { Sulfur }\end{array}$ & 0.47 & - & - & - & - & - & - & - & - & - & - & - & - & - \\
\hline Cystein & - & - & - & - & - & - & - & - & - & - & - & - & - & - \\
\hline Methionine & 0.14 & - & - & - & - & - & - & - & - & - & - & - & - & - \\
\hline Taurine & 0.02 & 0.01 & 0.01 & 0.04 & 0.02 & 0.01 & - & - & 0.01 & - & 0.06 & 0.06 & 0.01 & 0.01 \\
\hline$\beta$-alanine & 0.10 & 0.29 & 0.34 & 0.29 & 0.22 & 0.58 & 0.23 & 0.09 & 0.08 & 0.14 & 0.12 & 0.17 & 0.15 & 0.06 \\
\hline$\beta$-aminobutyric acid & 0.14 & 0.12 & 0.14 & 0.17 & 0.19 & - & 0.16 & 0.08 & 0.09 & 0.12 & 0.12 & 0.22 & 0.13 & 0.14 \\
\hline Total & $\overline{31.51}$ & $\overline{5.97}$ & $\overline{4.16}$ & $\overline{13.17}$ & $\overline{9.62}$ & $\overline{4.36}$ & $\overline{3.52}$ & $\overline{2.03}$ & $\overline{5.56}$ & $\overline{3.40}$ & $\overline{10.07}$ & $\overline{9.24}$ & $\overline{4.89}$ & $\overline{6.60}$ \\
\hline
\end{tabular}

5. The important compositional characteristic of much lower concentrations of acidic amino acid fractions in DFAA than in THAA in the interstitial waters from Hole $677 \mathrm{~A}$ is probably due to the reaction between acidic amino acids and carbonate.

\section{ACKNOWLEDGMENTS}

The authors appreciate Prof. S. D. Scott's efforts in helping Kawahata join the Leg 111 cruise of the Ocean Drilling Program while he was at the University of Toronto. They express their sincere thanks to Prof. J. K. Whelan, Prof. V. Ittekkot, and other two reviewers for comments that helped improve the manuscript. They wish to acknowledge Drs. I. Koike and M. Ohmori for providing technical advice on the analytical procedure. Also, they are grateful to Mr. T. Gustafson and Ms. T. J. Frank for Rock-Eval analysis aboard JOIDES Resolution. This work was partially supported by a Research Grant of the Agency of Industrial Science and Technology and Ministry of Education.

\section{REFERENCES}

Abelson, P. H., 1959. Geochemistry of organic substances. In Abelson, P. H. (Ed.), Researches in Geochemistry: New York (Wiley), 79-103. Anderson, R. N., and Skilbeck, J. N., 1981. Oceanic heat flow. In Emiliani, C. (Ed.), The Sea (vol. 7): New York (Wiley), 489-524.

Bada, J. L., Hoopes, E., and Ho, M.-S., 1982. Combined amino acids in Pacific Ocean waters. Earth Planet. Sci. Lett., 58:276-284.

Beiersdorf, H., and Natland, J. H., 1983. Sedimentary and diagenetic processes in the central Panama Basin since the late Miocene: the lithology and composition of sediments from DSDP Sites 504 and 505. In Cann, J. R., Langseth, M. G., Honnorez, J., Von Herzen, R. P., White, S. M., et al., Init. Repts. DSDP, 69: Washington (U.S. Govt. Printing Office), 343-383.

Beiersdorf, H., and Rosch, H., 1983. Mineralogy of sediments encountered during DSDP Leg 69 (Costa Rica Rift, Panama Basin), as de- termined by X-ray diffraction. In Cann, J. R., Langseth, M. G., Honnorez, J., Von Herzen, R. P., White, S. M., et al., Init. Repts. DSDP, 69: Washington (U.S. Govt. Printing Office), 385-393.

Carter, P. W., 1978. Adsorption of amino acid-containing organic matter by calcite and quartz. Geochim. Cosmochim. Acta, 42:12391242.

Carter, P. W., and Mittere, R. M., 1978. Amino acid composition of organic matter associated with carbonate and non-carbonate sediments. Geochim. Cosmochim. Acta, 42:1231-1238.

Gonzalez, J. M., Grimalt, J., and Albaiges, J., 1983. Amino acid composition of sediments from a deltaic environment. Mar. Chem., 14: 61-71.

Hedges, J. I., and Hare, P. E., 1987. Amino acid adsorption by clay minerals in distilled water. Geochim. Cosmochim. Acta, 51:255-259.

Henrichs, S. M., and Farrington, J. W., 1979. Amino acids in interstitial waters of marine sediments. Nature, 279:319-322.

1987. Early diagenesis of amino acids and organic matter in two coastal marine sediments. Geochim. Cosmochim. Acta, 51:1-15.

Henrichs, S. M., Farrington, J. W., and Lee, C., 1984. Peru upwelling region sediments near $15^{\circ} \mathrm{S} .2$. Dissolved free and total hydrolyzable amino acids. Limnol. Oceanogr., 29:20-34.

Ishizuka, T., Nozaki, Y., and Shimooka, K., 1988. Amino acids in the interstitial waters of ESOPE long cores from two North Atlantic abyssal plains. Geochem. J., 22:1-8.

Ittekkot, V., Deuser, W. G., and Degens, E. T., 1984. Seasonality in the fluxes of sugars, amino acids, and amino sugars to the deep ocean: Sargasso Sea. Deep-Sea Res., Part A, 31:1057-1069.

Jackson, T. A., and Bischoff, J. L., 1971. The influence of amino acids on the kinetics of the recrystallization of aragonite to calcite. $J$. Geol., 79:493-497.

Khan, S. O., and Sowden, F. J., 1972. Distributions of nitrogen in fulvic acid fractions extracted from the Black Solonetzic and Black Chernozemic soils of Alberta. Can. J. Soil. Sci., 52:116-119. 
Table 3 (continued).

\begin{tabular}{|c|c|c|c|c|c|c|c|c|c|c|c|c|c|c|c|}
\hline $\begin{array}{c}19 \times-4 \\
145-150 \\
169.5\end{array}$ & $\begin{array}{c}20 X-4 \\
145-150 \\
179.2\end{array}$ & $\begin{array}{c}22 \mathrm{X}-3 \\
120-125 \\
196.6\end{array}$ & $\begin{array}{c}23 \times-4 \\
145-150 \\
208.1\end{array}$ & $\begin{array}{c}24 X-4 \\
145-150 \\
217.7\end{array}$ & $\begin{array}{c}25 X-4 \\
120-125 \\
227.1\end{array}$ & $\begin{array}{c}26 \mathrm{X}-4 \\
145-150 \\
237.1\end{array}$ & $\begin{array}{c}27 X-4 \\
145-150 \\
246.8\end{array}$ & $\begin{array}{c}28 X-3 \\
120-125 \\
254.6\end{array}$ & $\begin{array}{c}29 X-3 \\
145-150 \\
264.5\end{array}$ & $\begin{array}{c}30 X-3 \\
145-150 \\
274.2\end{array}$ & $\begin{array}{c}31 \times-4 \\
120-125 \\
285.0\end{array}$ & $\begin{array}{c}32 X-4 \\
145-150 \\
294.9\end{array}$ & $\begin{array}{c}33 X-2 \\
145-150 \\
301.6\end{array}$ & $\begin{array}{c}33 \times-4, \\
145-150 \\
304.6\end{array}$ & $\begin{array}{r}33 X-3, \\
133-150 \\
303.0\end{array}$ \\
\hline 0.32 & 2.03 & 0.41 & 0.42 & 0.13 & 0.33 & - & - & - & 0.03 & 0.93 & 0.43 & 0.11 & - & 0.46 & 0.08 \\
\hline 1.18 & 4.32 & 1.75 & 1.09 & 0.45 & 1.36 & 0.35 & 0.09 & - & 0.51 & 3.20 & 16.25 & 1.03 & 0.17 & 1.94 & 0.68 \\
\hline 0.52 & 0.54 & 0.73 & 0.63 & 0.35 & 0.63 & 0.68 & 0.52 & 1.28 & 0.96 & 2.37 & 1.11 & 0.95 & 1.06 & 1.88 & 1.25 \\
\hline 0.19 & 1.01 & 0.18 & 0.18 & 0.10 & 0.18 & 0.17 & 0.16 & 0.32 & 0.18 & 0.38 & 0.53 & 0.21 & 0.16 & 0.35 & 0.14 \\
\hline- & 0.43 & 0.17 & 0.14 & 0.07 & 0.18 & 0.19 & 0.07 & 0.03 & 0.23 & 0.41 & 0.32 & 0.17 & 0.21 & 0.46 & 0.08 \\
\hline 0.04 & 1.12 & 0.05 & 0.05 & 0.01 & 0.02 & 0.03 & 0.02 & 0.03 & 0.02 & 0.14 & 0.17 & 0.02 & 0.03 & 0.03 & 0.03 \\
\hline 0.25 & 1.61 & 0.39 & 0.22 & 0.14 & 0.22 & - & - & - & - & 0.56 & 0.83 & 0.75 & - & 0.23 & - \\
\hline 0.94 & 2.02 & 1.38 & 0.83 & 0.43 & 0.91 & 0.44 & 0.09 & - & 0.41 & 2.88 & 1.72 & 0.78 & 0.41 & 1.61 & 0.63 \\
\hline 1.24 & 3.31 & 1.67 & 1.09 & 0.66 & 1.29 & 0.56 & 0.29 & 0.20 & 0.68 & 2.80 & 2.12 & 1.07 & 0.57 & 1.97 & 0.90 \\
\hline 0.74 & 1.91 & 1.05 & 0.60 & 0.46 & 0.69 & 0.18 & 0.56 & - & 0.20 & 1.30 & 2.81 & 0.49 & 0.22 & 0.90 & 0.44 \\
\hline 0.32 & 1.56 & 0.48 & 0.36 & 0.16 & 0.46 & - & - & - & 0.08 & 0.53 & 0.64 & 0.16 & 0.13 & - & 0.12 \\
\hline 0.06 & 1.06 & 0.59 & 0.04 & 0.01 & 0.07 & 0.06 & 0.01 & - & 0.10 & 0.75 & 0.69 & 0.74 & 0.60 & 0.60 & 0.54 \\
\hline 0.19 & 1.88 & 0.55 & 0.48 & 0.52 & 0.47 & 0.11 & 0.03 & - & 0.13 & 0.70 & 0.63 & 0.17 & 0.10 & 0.53 & 0.13 \\
\hline- & - & - & - & - & - & - & - & - & - & - & 1.25 & - & - & - & - \\
\hline- & 0.40 & 0.13 & 0.10 & - & - & - & - & - & - & 0.64 & 0.46 & 0.24 & 0.51 & 0.47 & 0.49 \\
\hline- & 0.23 & - & - & - & - & 0.07 & 0.10 & 0.10 & 0.16 & 0.27 & 0.21 & 0.44 & 0.16 & 0.36 & - \\
\hline- & - & - & - & - & - & - & - & - & - & - & - & - & - & - & - \\
\hline- & - & - & - & - & - & - & - & - & - & 0.02 & - & - & - & - & - \\
\hline 0.03 & 0.03 & 0.02 & - & - & 0.03 & - & - & - & - & - & 0.82 & - & - & - & - \\
\hline 0.05 & 0.07 & 0.13 & 0.04 & 0.08 & 0.05 & 0.09 & - & 0.01 & 0.03 & 0.04 & 0.01 & 0.20 & 0.01 & - & 0.02 \\
\hline 0.14 & 0.08 & 0.21 & 0.20 & 0.10 & 0.11 & - & - & - & - & 0.03 & 0.10 & - & - & - & - \\
\hline 6.21 & 23.61 & 9.89 & 6.47 & 3.67 & 7.00 & 2.93 & 1.94 & 1.97 & 3.79 & 17.95 & 31.10 & 7.53 & 4.34 & 11.79 & 5.53 \\
\hline
\end{tabular}

Langseth, M. G., Mottl, M. J., Hobart, M. A., and Fisher, A., 1988. The distribution of geothermal and geochemical gradients near Site 501/504: implications for hydrothermal circulation in the oceanic crust. In Becker, K., Sakai, H., et al., Proc. ODP, Init. Repts., 111: College Station, TX (Ocean Drilling Program), 23-32.

McIver, R., 1975. Hydrocarbon occurrence from Joides Deep Sea Drilling Project. Proc. Petrol. Congr., 9:269-280.

Michaelis, W., Mycke, B., Vogt, J., Schuetze, G., and Degens, E. T., 1982. Organic geochemistry of interstitial waters, Sites 474 and 479, Leg 64. In Curray, J. R., Moore, D. G., et al., Init. Repts. DSDP, 64: Washington (U.S. Govt. Printing Office), 933-937.

Morris, R. J., 1975. The amino acid composition of a deep-water marine sediment from the upwelling region northwest of Africa. Geochim. Cosmochim. Acta, 39:381-388.

Nissenbaum, A., Baodecker, M. J., and Kaplan, I. R., 1972. Organic geochemistry of Dead Sea sediments. Geochim. Cosmochim. Acta, 36:709-727.

Peake, E. P., Baker, B. L., and Hodgson, G. W., 1972. Hydrogeochemistry of the surface waters of the Mackenzie River drainage basin, Canada-II. The contribution of amino acids, hydrocarbons and chlorine to the Beaufort Sea by the Mackenzie River system. Geochim. Cosmochim. Acta, 36:867-883.

Pelet, R., and Debyser, Y., 1977. Organic geochemistry of Black Sea cores. Geochim. Cosmochim. Acta, 41:1575-1586.

Raymont, J.E.G., Morris, R. J., Ferguson, C. F., and Raymont, J.K.B., 1975. Variation in the amino-acid composition of lipid-free residues of marine animals from the northeast Atlantic. J. Exp. Mar. Biol. Ecol., 17:261-267.
Scientific Drilling Party, 1987. Costa Rica Rift hole deepened and logged. Geotimes, 8:14-16.

Shipboard Scientific Party, 1987. News from a deepening hole. Nature, $325: 484-485$.

, 1988. Sites 677 and 678. In Becker, K., Sakai, H., et al., Proc. ODP, Init. Repts., 111: College Station, TX (Ocean Drilling Program), 253-348.

Siezen, R. J., and Magne, T. H., 1978. Amino acids in suspended particulate matter from oceanic and coastal waters of the Pacific. Mar. Chem., 6:215-231.

Stevenson, F. J., and Cheng, C. N., 1969. Amino acid levels in the Argentine Basin sediments: correlation with Quaternary climatic changes. J. Sediment. Petrol., 39:345-349.

Tissot, B. P., and Welte, D. H., 1984. Petroleum Formation and Occurrence: Heidelberg (Springer Verlag).

Whelan, J. K., and Hunt, J. M., 1983. Organic matter in Deep Sea Drilling Project Site 504 and 505 sediments studied by a thermal analysis-gas chromatography technique. In Anderson, R. N., Honnorez, J., Becker, K., et al., Init. Repts. DSDP, 83: Washington (U.S. Govt. Printing Office), 443-450.

Whelan, J. K., and Tarafa, M., 1986. Organic matter in Leg 96 sediments: characterization by pyrolysis. In Bouma, A. H., Coleman, J. M., Meyer, A. W., et al., Init. Repts. DSDP, 96: Washington (U.S. Govt. Printing Office), 757-765.

Date of initial receipt: 27 October 1988

Date of acceptance: 22 March 1989

Ms 111B-130 
Table 4. Concentrations of DFAA in interstitial-water samples from Hole 677A.

\begin{tabular}{|c|c|c|c|c|c|c|c|c|c|c|c|c|c|c|}
\hline Depth (mbsf) & $\begin{array}{c}1 \mathrm{H}-3, \\
145-150 \\
4.5\end{array}$ & $\begin{array}{c}2 \mathrm{H}-1 \\
80-89 \\
7.0\end{array}$ & $\begin{array}{c}3 \mathrm{H}-4 \\
120-125 \\
21.4\end{array}$ & $\begin{array}{c}4 \mathrm{H}-1, \\
55-74 \\
25.8\end{array}$ & $\begin{array}{c}5 \mathrm{H}-1, \\
51-69 \\
35.3\end{array}$ & $\begin{array}{c}6 \mathrm{H}-3, \\
120-125 \\
48.4\end{array}$ & $\begin{array}{c}9 \mathrm{H}-3, \\
120-125 \\
76.9\end{array}$ & $\begin{array}{c}12 \mathrm{H}-4 \\
120-125 \\
106.9\end{array}$ & $\begin{array}{c}13 \mathrm{H}-4 \\
145-150 \\
116.7\end{array}$ & $\begin{array}{c}14 \mathrm{H}-4 \\
145-150 \\
126.2\end{array}$ & $\begin{array}{c}15 \mathrm{H}-4, \\
120-125 \\
135.4\end{array}$ & $\begin{array}{c}16 X-4 \\
145-150 \\
145.2\end{array}$ & $\begin{array}{c}17 X-3 \\
145-150 \\
148.7\end{array}$ & $\begin{array}{c}18 \mathrm{X}-3, \\
120-125 \\
158.0\end{array}$ \\
\hline \multicolumn{15}{|l|}{ Acidic } \\
\hline Aspartic acid & 0.24 & 0.10 & 0.08 & 0.43 & 0.18 & 0.03 & 0.02 & - & 0.09 & 0.01 & 0.11 & - & 0.13 & 0.18 \\
\hline Glutamic acid & 0.16 & - & 0.13 & 0.16 & 0.08 & 0.04 & - & - & 0.06 & 0.06 & 0.08 & 0.20 & 0.14 & - \\
\hline \multicolumn{15}{|l|}{ Basic } \\
\hline Ornithine & 0.21 & 0.13 & 0.07 & 0.68 & 0.41 & 0.09 & 0.14 & 0.12 & 0.29 & 0.20 & 0.02 & - & 0.35 & 0.48 \\
\hline Lysine & 0.08 & 0.06 & - & 0.23 & 0.12 & 0.05 & 0.05 & 0.04 & 0.09 & 0.04 & 0.09 & - & 0.07 & 0.14 \\
\hline Histidine & 0.11 & 0.06 & - & 0.16 & 0.09 & 0.05 & 0.04 & 0.01 & 0,09 & 0.04 & 0.08 & - & 0.07 & 0.18 \\
\hline Arginine & 0.01 & 0.03 & - & 0.00 & - & - & - & - & 0.02 & - & - & - & 0.01 & 0.02 \\
\hline \multicolumn{15}{|l|}{ Neutral } \\
\hline \multicolumn{15}{|l|}{ Hydroxy } \\
\hline Threonine & 0.21 & 0.11 & 0.05 & 0.33 & 0.12 & - & 0.03 & - & 0.08 & 0.02 & 0.11 & - & 0.14 & 0.21 \\
\hline Serine & 0.67 & 0.29 & 0.11 & 1.44 & 0.65 & 0.19 & 0.28 & 0.08 & 0.57 & 0.26 & 0.52 & - & 0.43 & 0.88 \\
\hline \multicolumn{15}{|l|}{ Straight } \\
\hline Glycine & 0.91 & 0.51 & 0.37 & 1.76 & 0.90 & 0.40 & 0.47 & 0.22 & 0.73 & 0.48 & 0.75 & - & 0.66 & 1.25 \\
\hline Alanine & 0.67 & 0.32 & 0.27 & 1.11 & 0.58 & 0.34 & 0.33 & 0.22 & 0.48 & 0.36 & 0.47 & - & 0.46 & 0.69 \\
\hline \multicolumn{15}{|l|}{ Branch } \\
\hline Valine & 0.35 & - & - & - & - & - & - & - & - & - & - & - & - & 0.28 \\
\hline Iso-leucine & 0.04 & 0.01 & 0.01 & 0.11 & 0.03 & 0.01 & 0.01 & 0.01 & 0.04 & 0.02 & 0.03 & - & 0.01 & 0.07 \\
\hline Leucine & 0.18 & - & - & 0.47 & 0.10 & 0.36 & - & - & 0.10 & 0.31 & - & - & 0.07 & 0.47 \\
\hline \multicolumn{15}{|l|}{ Others } \\
\hline Aspargine & - & - & - & 0.04 & - & - & - & - & - & - & 0.07 & - & 0.09 & 0.13 \\
\hline \multicolumn{15}{|l|}{ Aromatic } \\
\hline Tyrosine & - & - & - & - & - & - & - & - & - & - & - & - & - & - \\
\hline $\begin{array}{l}\text { Phenylalanine } \\
\text { Sulfur }\end{array}$ & - & - & - & - & - & - & - & - & - & - & - & - & - & - \\
\hline Cystein & - & - & - & - & - & - & - & - & - & - & - & - & - & - \\
\hline Methionine & - & - & - & - & - & - & - & - & - & - & - & - & - & - \\
\hline Taurine & 0.02 & - & - & - & - & - & - & - & - & - & - & - & - & - \\
\hline$\beta$-alanine & 0.10 & 0.18 & 0.03 & 0.10 & - & - & - & - & - & 0.02 & 0.02 & - & 0.02 & - \\
\hline$\beta$-aminobutyric acid & 0.07 & - & - & - & - & - & - & - & - & - & - & - & $二$ & - \\
\hline Total & $\overline{4.03}$ & $\overline{1.80}$ & $\overline{1.12}$ & $\overline{7.02}$ & $\overline{3.26}$ & $\overline{1.56}$ & $\overline{1.37}$ & $\overline{0.70}$ & $\overline{2.64}$ & $\overline{1.82}$ & 2.35 & 0.20 & 2.65 & 4.98 \\
\hline
\end{tabular}


Table 4 (continued).

\begin{tabular}{|c|c|c|c|c|c|c|c|c|c|c|c|c|c|c|c|}
\hline $\begin{array}{c}19 X-4 \\
145-150 \\
169.5\end{array}$ & $\begin{array}{c}20 X-4 \\
145-150 \\
179.2\end{array}$ & $\begin{array}{c}22 \mathrm{X}-3 \\
120-125 \\
196.6\end{array}$ & $\begin{array}{c}23 \times-4 \\
145-150 \\
208.1\end{array}$ & $\begin{array}{c}24 X-4 \\
145-150 \\
217.7\end{array}$ & $\begin{array}{c}25 X-4 \\
120-125 \\
227.1\end{array}$ & $\begin{array}{c}26 \mathrm{X}-4 \\
145-150 \\
237.1\end{array}$ & $\begin{array}{c}27 X-4 \\
145-150 \\
246.8\end{array}$ & $\begin{array}{c}28 X-3 \\
120-125 \\
254.6\end{array}$ & $\begin{array}{c}29 X-3 \\
145-150 \\
264.5\end{array}$ & $\begin{array}{c}30 \mathrm{X}-3 \\
145-150 \\
274.2\end{array}$ & $\begin{array}{c}31 X-4 \\
120-125 \\
285.0\end{array}$ & $\begin{array}{c}32 \times-4 \\
145-150 \\
294.9\end{array}$ & $\begin{array}{c}33 X-2 \\
145-150 \\
301.6\end{array}$ & $\begin{array}{c}33 X-4 \\
145-150 \\
304.6\end{array}$ & $\begin{array}{c}33 \mathrm{X}-3 \text {, } \\
133-150 \\
303.0\end{array}$ \\
\hline 0.21 & 0.21 & 0.32 & 0.24 & 0.13 & 0.18 & - & - & - & - & 0.35 & - & - & - & 0.21 & - \\
\hline 0.20 & 0.08 & 0.19 & 0.18 & 0.14 & - & - & - & - & - & - & - & - & - & - & - \\
\hline- & 0.40 & 0.63 & 0.53 & 0.35 & 0.48 & 0.47 & 0.38 & 0.89 & 0.65 & 2.37 & 0.70 & 0.70 & 0.55 & 1.17 & 0.13 \\
\hline- & 0.12 & 0.15 & 0.13 & 0.07 & 0.14 & 0.13 & 0.10 & 0.23 & 0.17 & 0.33 & 0.17 & 0.21 & 0.14 & 0.03 & - \\
\hline- & 0.06 & 0.17 & 0.11 & 0.07 & 0.18 & 0.15 & 0.05 & - & 0.15 & 0.37 & 0.17 & 0.17 & 0.21 & 0.18 & - \\
\hline 0.02 & 0.01 & 0.02 & 0.03 & 0.01 & 0.02 & - & 0.02 & - & - & 0.04 & - & 0.02 & 0.03 & - & - \\
\hline 0.25 & 0.24 & 0.39 & 0.22 & 0.14 & 0.21 & - & - & - & - & 0.36 & - & 0.75 & - & 0.17 & - \\
\hline 0.94 & 0.83 & 1.38 & 0.75 & 0.43 & 0.88 & 0.44 & 0.09 & - & 0.38 & 2.28 & 0.88 & - & 0.29 & 0.48 & 0.13 \\
\hline 1.24 & 1.03 & 1.67 & 1.01 & 0.66 & 1.25 & 0.55 & 0.15 & - & 0.35 & 2.23 & 0.92 & 0.78 & 0.33 & 0.41 & 0.14 \\
\hline 0.73 & 0.63 & 1.05 & 0.60 & 0.46 & 0.69 & 0.18 & 0.56 & - & 0.11 & 1.12 & 0.43 & 0.29 & 0.08 & 0.25 & 0.10 \\
\hline- & 0.36 & 0.15 & 0.32 & - & 0.28 & - & - & - & 0.07 & - & 0.17 & 0.16 & 0.13 & - & - \\
\hline- & 0.05 & 0.12 & 0.04 & 0.01 & 0.07 & 0.03 & - & - & 0.03 & 0.75 & 0.07 & 0.07 & 0.60 & 0.36 & 0.18 \\
\hline- & 0.45 & 0.20 & 0.13 & 0.07 & 0.47 & 0.07 & - & - & - & 0.68 & 0.16 & - & - & 0.21 & 0.07 \\
\hline 0.19 & 0.13 & 0.19 & 0.13 & 0.09 & 0.13 & - & - & - & - & - & - & - & - & - & - \\
\hline- & - & - & - & - & - & - & - & - & - & 0.64 & 0.46 & 0.24 & - & 0.15 & - \\
\hline- & - & - & - & - & - & 0.07 & 0.10 & 0.06 & 0.11 & 0.25 & - & 0.15 & 0.02 & 0.03 & - \\
\hline- & - & - & - & - & - & - & - & - & - & - & - & - & - & - & - \\
\hline- & - & - & - & - & - & - & - & - & - & 0.02 & - & - & - & - & - \\
\hline- & 0.01 & 0.02 & - & - & - & - & - & - & - & - & - & - & - & - & - \\
\hline 0.02 & 0.02 & 0.02 & - & 0.02 & - & - & - & - & - & - & - & - & - & - & - \\
\hline 0.03 & - & - & - & - & - & - & - & - & - & 0.03 & 0.10 & - & - & - & - \\
\hline 3.83 & $\overline{4.63}$ & $\overline{6.67}$ & $\overline{4.42}$ & $\overline{2.65}$ & $\overline{4.98}$ & $\overline{2.09}$ & $\overline{1.45}$ & $\overline{1.18}$ & $\overline{2.02}$ & $\overline{11.82}$ & $\overline{4.23}$ & 3.54 & 2.38 & 3.65 & 0.75 \\
\hline
\end{tabular}




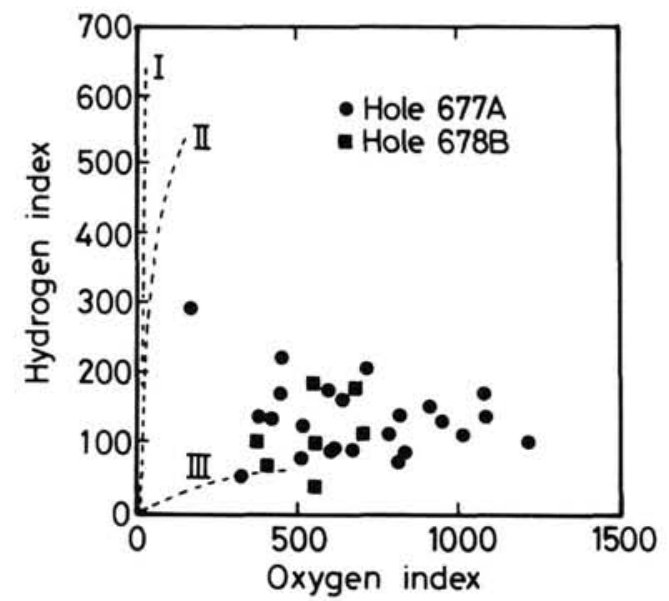

Figure 4. HI vs. OI (van Krevelen diagram) of organic matter at Holes $677 \mathrm{~A}$ and $678 \mathrm{~B}$.
Pore water (Free) Pore water (Hydr.)

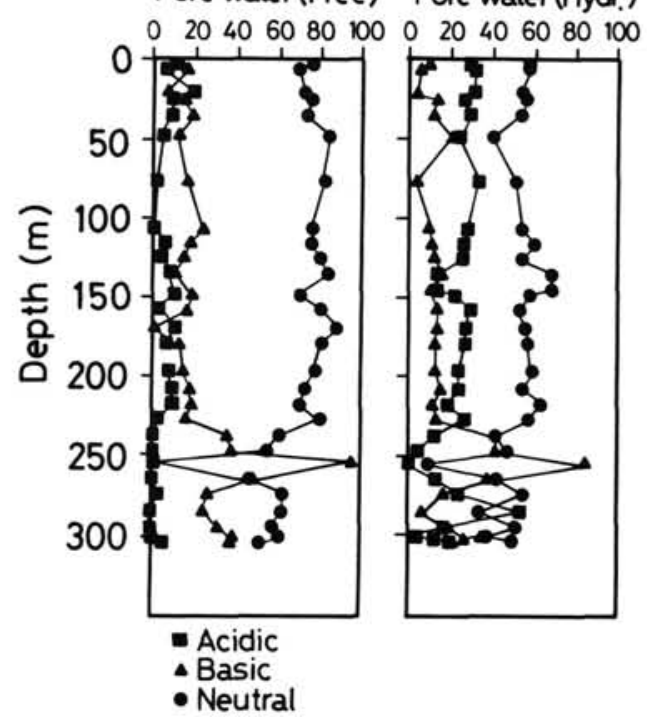

Figure 5. Relative abundances of acidic, basic, and neutral fractions of DFAA and THAA amino acids vs. sub-bottom depth in Hole 677A.
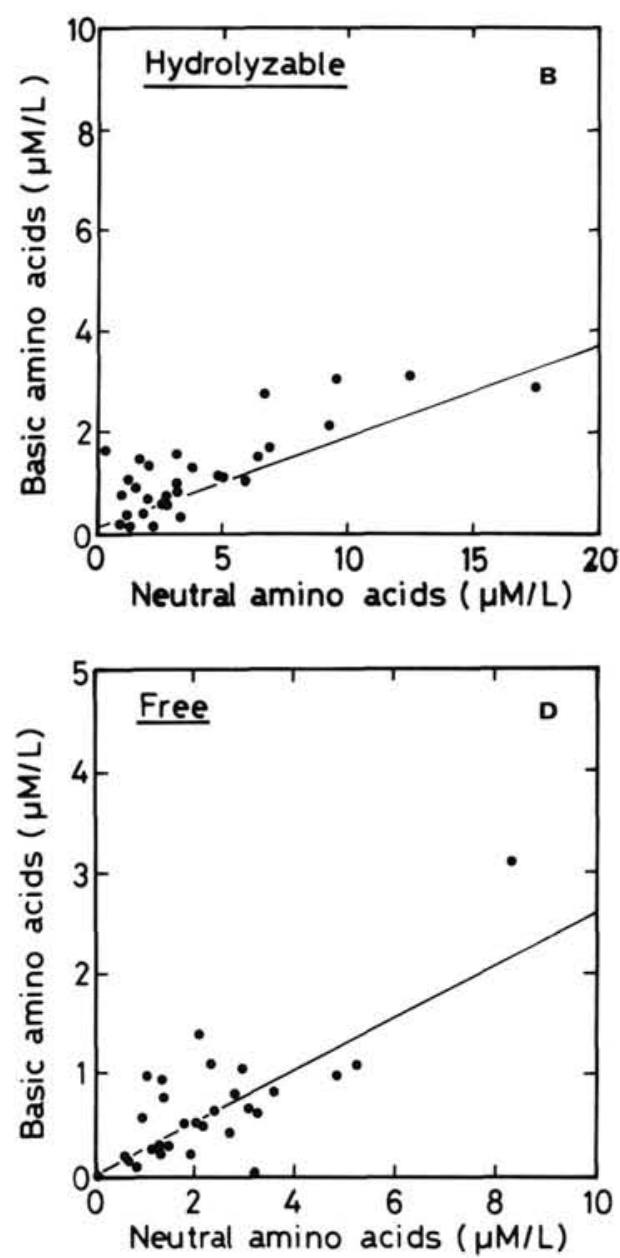

Figure 6. A. Acidic amino acids vs. neutral amino acids of THAA from Hole 677A. B. Basic amino acids vs. neutral amino acids of THAA from Hole 677A. C. Acidic amino acids vs. neutral amino acids of DFAA from Hole 677A. D. Basic amino acids vs. neutral amino acids of DFAA from Hole 677A. 
Table 5. The relative abundance of amino acids in interstitial-water DFAA and THAA, marine plankton, and suspended matter.

\begin{tabular}{|c|c|c|c|c|c|}
\hline & $\begin{array}{c}\text { DFAA } \\
(\mathrm{mol} \%)\end{array}$ & $\begin{array}{l}\text { THAA } \\
(\mathrm{mol} \%)\end{array}$ & $\begin{array}{r}\text { Marine } \\
\text { plankton }^{a} \\
(\mathrm{~mol} \%)\end{array}$ & $\begin{array}{c}\text { Marine } \\
\text { suspension } \\
(\mathrm{mol} \%)\end{array}$ & $\begin{array}{c}\text { River } \\
\text { suspension } \\
(\mathrm{mol} \%)\end{array}$ \\
\hline Acidic & 8.2 & 22.6 & 20.4 & 25.3 & 24.9 \\
\hline Aspartic acid & 2.9 & 4.8 & 9.0 & 16.7 & 13.1 \\
\hline Glumatic acid & 5.2 & 17.7 & 11.5 & 8.6 & 11.8 \\
\hline Basic & 22.4 & 19.0 & 17.4 & 14.5 & 3.0 \\
\hline Ornithine & 15.3 & 12.8 & 1.0 & 0.1 & 0.9 \\
\hline Lysine & 3.8 & 3.3 & 8.2 & 8.6 & 2.1 \\
\hline Histidine & 3.0 & 2.0 & 2.2 & 1.9 & $*$ \\
\hline Arginine & 0.3 & 0.9 & 6.0 & 3.9 & $*$ \\
\hline $\begin{array}{l}\text { Neutral } \\
\text { Hydroxy }\end{array}$ & 66.7 & 51.5 & 48.8 & 51.6 & 61.2 \\
\hline Threonine & 3.5 & 3.1 & 4.9 & 5.0 & 4.0 \\
\hline $\begin{array}{l}\text { Serine } \\
\text { Straight }\end{array}$ & 15.4 & 10.8 & 6.2 & 7.2 & 6.7 \\
\hline Glycine & 22.6 & 16.3 & 12.1 & 17.9 & 18.3 \\
\hline Alanine & 15.2 & 7.5 & 8.5 & 9.6 & 14.8 \\
\hline Branch & & & & & \\
\hline Valine & 1.8 & 4.3 & 5.5 & 5.0 & 6.2 \\
\hline Iso-leucine & 3.0 & 3.4 & 4.6 & 2.5 & 3.0 \\
\hline $\begin{array}{l}\text { Leucine } \\
\text { Others }\end{array}$ & 4.2 & 5.8 & 7.1 & 4.4 & 8.3 \\
\hline Aspargine & 1.0 & 0.2 & • & * & * \\
\hline Aromatic & 1.9 & 2.6 & 6.8 & 5.2 & 3.5 \\
\hline Tyrosine & 0.9 & 1.5 & 3.2 & 2.5 & 0.8 \\
\hline Phenylalanine & 1.0 & 1.2 & 3.5 & 2.7 & 2.7 \\
\hline Sulfur & 0.0 & 0.0 & 3.7 & * & 0.3 \\
\hline Cystein & 0.0 & 0.0 & 1.1 & * & $*$ \\
\hline Methionine & 0.0 & 0.0 & 2.6 & * & 0.3 \\
\hline
\end{tabular}

Note: * = Data not reported.

${ }^{a}$ Raymont et al. (1975).

${ }^{b}$ Below $3000 \mathrm{~m}$ water depth, equatorial Pacific Ocean (Ittekkot et al., 1984).

${ }^{c}$ Average of river suspensions (Peake et al., 1972). 